\title{
Comparative Analysis: A Minimum Music Materials Budget for the University Library
}

\begin{abstract}
An analysis of the 1969/70 music materials budgets of forty-six university libraries, forty-four in the United States and two in Canada, which illustrates both the value of and the need for library statistical information at the subject level in order to validate more specifically increased budget requests. The study presents statistical information of special interest to music librarians attempting to establish a minimum annual budget where a maximum one is not possible.
\end{abstract}

0 NE COMMON QUESTION, "Is our bookfund budget large enough to support the total faculty and student needs of the various academic departments within the university?" is frequently raised by the administrators of university libraries. Often the answer seems to be a negative one. The library administrator's answer to this question is usually based on the increased budget requests of his division heads for the coming year. The division head gathers this information either from the library subject specialists who work in that division or directly from the department head, e.g., a music library in which the department head is also the subject specialist.

The primary source of the budget information which builds the overall bookfund request for a university library system is therefore the judgment of library subject specialists and faculty members as to the needs of their subject area. This assessment of needs is based on special

Mr. Brazell is Assistant Humanities Librarian in charge of Music and Performing Arts at Eastern Michigan University, Ypsilanti, Michigan. subject knowledge which illuminates gaps in the subject collection and serves to define curriculum goals which would necessitate collection building. Without the vital assessments of subject specialists, the book-fund budget requests of library administrators would be even more of a guess than they are with those assessments.

The validity of the budget recommendations of library subject specialists rests on two very subjective criteria. These are (1) the quality of the subject specialist's judgment in the subject area and (2) his communications with the subject academic department which he serves in the library. The quality of the subject specialist's judgment varies, however, and there is no tangible gauge of validity of judgment implicit in credentials or publications lists which can finally assure the library administrator that the budget recommendation of the subject specialist is indeed objective and relevant.

Also, the problems of communications with subject department faculty on curriculum goals are many and varied. The rigid administrative structures of many libraries often do not allow subject li- 
brarians in the lower administrative positions the freedom to communicate as equals with academic faculty.

Another communications problem is that faculty members of academic departments often do not understand the role of the subject librarian in the development of reasonable curriculum goals for their subject departments. Further, curriculum goals are sometimes not very clearly defined in the academic departments. Thus the problems of communication with academic departments for the development of valid book-fund budget recommendations are great indeed.

There is a desperate need to establish objective criteria at the subject level for validating budget recommendations by librarians and faculty. This study is an attempt to delineate a budget profile, based on size, in order to develop a more valid music materials budget recommendation for a university library. Its main purpose is to determine the adequacy of current budgetary expenditures by the university library for music materials by comparing current annual expenditures for music media with those of other universities.

The data for the study were collected by means of a questionnaire which was mailed in January 1970 to ninety-eight university libraries in the United States and Canada. ${ }^{1}$ These libraries were identified as having significant music collections and/or phonorecord libraries. The only criteria for inclusion of a library in the study were that the library must be in a four-year college or university in the United States or Canada and that it must have a music collection and/or phonorecord collection. The questionnaires were sent specifically to music librarians in those institutions where one existed; in other cases, they were sent to humanities or fine arts librarians or audiovisual specialists in the library.

Forty-six of ninety-eight libraries re- sponded, for an overall return of 47 percent. Table 1 lists the responding libraries. Twenty-eight percent of them represented libraries in universities with enrollments under 15,000 full-time enrolled (FTE) students, 41 percent were from universities with 15,000 to 25,000 FTE students, and 30 percent were from universities with over 25,000 FTE students. In this report these groups will be referred to as Groups I, II, and III, respectively. All enrollment statistics in this report are FTE figures.

The purpose of dividing the respondents into these three groups is to develop a mean and a median library budget for music materials for each of the three groups. These statistics would enable a music librarian and other library administrators to compare their own expenditures for music materials with a mean and a median figure derived from a sample of libraries in universities of comparable enrollment. It is hoped that the perspective gained from this approach might contribute to a more objective validation of book-fund expenditures.

\section{The ANALYsis of UnIVERSITY Library Music Material Budgets}

\section{Mean and Median Budgets}

Thirty-eight of the forty-six libraries returning questionnaires responded to the appropriate question asking for the total budget for purchase of music materials including scores, books about music, and phonorecords. (See Table 2 for a detailed breakdown.) In computing the mean budget for music materials for each enrollment group, both the high and low responses were omitted to achieve a more representative mean for each group.

The mean music materials budget for libraries responding from Group I universities was found to be $\$ 6,094$, Group II was $\$ 13,361$, and Group III was $\$ 17$,- 
TABLE 1

\section{Universities with enrollments under 15,000 FTE students}

Arkansas, University of Butler University Case Western Reserve University

Catholic University of America

Hartford, University of

Laval Université (Québec)

New Mexico, University of

Princeton University

Rochester, University of

Texas Christian University

Tulane University

Washington University (St. Louis)

Wichita State University
AudioVisual Area
Music Library
Music House Library
Music Library
Music Library
Music Library-School of Music
Fine Arts Library
Phonograph Record Library
Music Library
Music Library-School of Fine Arts
Maxwell Music Library
Gaylord Music Library
Music Library-School of Music

Universities with enrollments of 15,000 to 25,000 FTE students

Boston University

Eastern Michigan University

Florida State University

Fresno State College

Georgia, University of

Harvard University

Houston, University of

Louisiana State University

Miami, University of

Nebraska, University of

North Carolina, University of

North Texas State University

Northern Illinois University

Northwestern University

Pittsburgh, University of

Queens College (CUNY)

Tennessee, University of

Utah, University of

Western Michigan University
University Library

University Library

Warren D. Allen Music Library

Music Library-Fresno State College Library

University Library

Music Library

University Library

University Library

Music Library

University Library

Music Library

Music Library

Swen Franklin Parson Library

Music Library

Music Library

Music Library

Music Library-Dept. of Music

University Library

Music Library

Universities with enrollments of more than 25,000 FTE students

California State College (Long Beach)

California, University at Los Angeles

Colorado, University of

Illinois, University of (Urbana)

Indiana, University of (Bloomington)

Michigan, University of

Michigan State University

Northeastern University

San Francisco State College

Temple University

Texas, University of

Toronto, University of

Washington, University of

Wisconsin. University of
University Library

Music Library

Norlin Library

Music Library-School of Music

School of Music Library

Music Library-School of Music

Audio Library-Main Library

Dodge Library

College Library

University Library

Music Library

Edward Johnson Music Library

Music Library

Mills Music Library
124. The overall mean expenditure for music materials of all thirty-eight libraries responding was found to be $\$ 14,178$.

The median (i.e., one-half of the respondents are above the figure, and one-half are below it) music materials budget for libraries responding from Group I was $\$ 6,000$ (mean: $\$ 6,094$ ); Group II was $\$ 13,000$ (mean: $\$ 13,361$ );
Group III was $\$ 14,250$ (mean: $\$ 17,123$ ). The overall median budget for music materials of all thirty-eight libraries was $\$ 10,750$ (overall mean: $\$ 14,178$ ).

\section{Mean and Median FTE Music Major Enrollments}

The mean number of music majors enrolled full-time was Group I, 263; 
TABLE 2

1969-70 UnIVERSity LibraRy EXPENDITURES For MuSic Materials

\begin{tabular}{|c|c|c|c|}
\hline School & $\begin{array}{l}\text { Average Budget for } \\
\text { Music Materials }\end{array}$ & $\begin{array}{l}\text { Library Book- } \\
\text { Fund Budget }\end{array}$ & $\begin{array}{l}\text { Percent of Book- } \\
\text { Fund Budget Used } \\
\text { for Music Materials }\end{array}$ \\
\hline
\end{tabular}

Enrollments under 15,000

$\begin{array}{lr}\text { A } & \$ 2,500 \\ \text { D } & 5,000 \\ \text { C } & 2,300 \\ \text { E } & 7,000 \\ \text { F } & 7,000 \\ \text { G } & 3,581 \\ \text { I } & 53,000 \\ \text { J } & 9,175 \\ \text { L } & 11,000 \\ \text { M } & 3,500\end{array}$

$\$ 233,994$
266,818
600,000
no response
no response
458,000
no response
no response
no response
no response

$\begin{array}{lc}1.0 & \text { percent } \\ 1.8 & " \\ .38 & " \\ - & " \\ .78 & " \\ - & " \\ - & \prime \prime\end{array}$

Analysis: Omitting high and low responses, the mean budget for music materials equals $\$ 6,094.50$.

Enrollments of 15,000 to 25,000

\begin{tabular}{|c|c|c|c|c|}
\hline O & $\$ 6,292$ & $\$ 285,261$ & 2.2 & percent \\
\hline $\mathrm{P}$ & 13,000 & no response & & \\
\hline $\mathrm{R}$ & 21,620 & $1,226,021$ & 1.8 & $"$ \\
\hline $\mathrm{S}$ & 29,800 & no response & - & $"$ \\
\hline $\mathrm{T}$ & 4,250 & 521,426 & .81 & $"$ \\
\hline$\hat{U}$ & 6,452 & 266,942 & 2.4 & $"$ \\
\hline V & 12,000 & no response & - & $"$ \\
\hline W & 5,600 & 691,000 & .81 & $"$ \\
\hline $\mathrm{x}$ & 25,000 & no response & - & " \\
\hline $\mathrm{Y}$ & 21,500 & no response & - & $"$ \\
\hline $\mathrm{Z}$ & 20,300 & 621,660 & 3.3 & $"$ \\
\hline $\mathrm{AA}$ & 23,400 & 850,000 & 2.75 & $"$ \\
\hline $\mathrm{BB}$ & 2,500 & 450,000 & .56 & $"$ \\
\hline CC & 15,000 & no response & - & $"$ \\
\hline DD & 6,500 & no response & - & $"$ \\
\hline $\mathrm{EE}$ & 5,500 & 355,000 & 1.5 & $"$ \\
\hline FF & 14,000 & 400,000 & 1.5 & $"$ \\
\hline
\end{tabular}

Analysis: Omitting high and low responses, the mean budget for music materials equals $\$ 13,360.93$.

Enrollments over 25,000

\begin{tabular}{|c|c|c|c|c|}
\hline GG & $\$ 37,000$ & $\$ 750,000$ & 4.9 & percent \\
\hline $\mathrm{HH}$ & 26,000 & $1,534,932$ & 1.7 & \\
\hline II & 11,000 & no response & - & " \\
\hline $\mathrm{JJ}$ & 32,000 & no response & - & $"$ \\
\hline KK & 24,000 & no response & - & " \\
\hline MM & 5,900 & $1,150,576$ & .51 & $"$ \\
\hline LL & 17,213 & no response & - & $"$ \\
\hline NN & no response & 400,000 & - & " \\
\hline $\mathrm{OO}$ & 10,500 & 338,782 & 3.0 & $"$ \\
\hline$Q Q$ & 9,600 & no response & - & $"$ \\
\hline S & 14,250 & 801,000 & 1.8 & $"$ \\
\hline TT & 9,550 & $1,083,747$ & .88 & " \\
\hline
\end{tabular}

Analysis: Omitting high and low responses, the mean budget for music materials equals $\$ 17,123.67$.

Group II, 327; Group III, 510. The overall mean enrollment of music majors for the thirty-five universities represented by responses was 403 FTE music majors. The median number of music majors enrolled full-time was Group I, 247 (mean: 263); Group II, 310 (mean: 327); and Group III, 495 (mean: 150). The overall median enrollment for the thirty-five universities represented by re- 
sponses to the appropriate question was 330 music majors (overall mean: 403).

\section{University Library Music Material Ex- penditures per Music Major}

One way to give more meaning to library budget figures is to relate them to the number of clientele served in order to derive per-capita expenditure statistics. Table 3 gives the detailed breakdown of mean music material expenditures per music major.

The median library expenditure for music materials was (approximately), $\$ 28$ per FTE music major (mean: \$41), Group I; \$31 (mean: \$48), Group II; and \$24 (mean: \$31), Group III. The overall median library expenditure of the thirty-five libraries responding was about $\$ 26$ per FTE music major (overall mean: \$36 per FTE music major).

\section{Rankings of Universities}

The 1969-70 rankings of the universities responding as to numbers of music majors enrolled in the university, the library's music materials budget, and the library's expenditure per FTE music major are given in Table 4.

\section{An "Ideal" Music Materials BUDGET FOR A UNIVERSITY LIBRARY}

It is a difficult task to arrive at an "ideal" music materials budget for a university library. Such a budget would have to have as its cornerstones a standard list of scores, books about music, and phonorecords. Although many such lists have been published, they are rarely comprehensive, always out of date, and rarely ever selective enough for university music library collections. Therefore a music materials budget based only on a standard list would build a music materials collection which would have all the aforementioned failings of the standard list itself. Furthermore, every university music department is unique in terms of curriculum directions and faculty qualifications and interest in various subject areas within the field of music. These unique features create variations in the needs and content of each music collection which defy standardization.

If, however, a standard list is taken as a comparative minimum guide to building a music collection, it can be of some use in building that collection. Thus, an "ideal" minimum music materials budget, derived from comparison with the clientele served and music materials budgets of other university libraries which serve universities of similar FTE enrollments, could be used as a guide to the validity of music materials budget recommendations.

This study has provided three such tentative models for use in evaluating the adequacy of music materials budgets. These models are based on a sample of the university libraries which contain music collections. Further studies are necessary to build more dependable models.

These three models can be defined in two ways: (1) by using the mean and median music materials budgets of each enrollment group as comparative guides to the minimum effective materials budget needed for libraries in universities in that group; and (2) by using the mean and median university library expenditures per music major as comparative guides to the minimum effective library expenditure per music major necessary to support the primary users of those materials.

Using the data from this study, the three models are:

For libraries in Group I universitiesMinimum annual music materials budget: $\$ 6,000$ (median) to $\$ 6,094$ (mean); music major enrollment: 274 students (median) to 263 students (mean); minimum annual library expenditures per music major: $\$ 28$ (median) to $\$ 41$ (mean). 
For libraries in Group II universitiesMinimum annual music materials budget: $\$ 13,000$ (median) to $\$ 13,361$ (mean); music major enrollment: 310 students (median) to 327 students (mean); minimum annual library expenditures per music major: $\$ 31$ (median) to $\$ 48$ (mean).

For libraries in Group III universities -Minimum annual music materials budget: $\$ 14,250$ (median) to $\$ 17,123$ (mean); music major enrollment: 495 students (median) to 510 students (mean); minimum annual library expenditures per music major: \$24 (median) to $\$ 31$ (mean).

\section{Conclusions}

\section{A Minimum Annual Library Expendi- ture for Music Materials}

The closely corresponding mean and median data from this study suggest that libraries in universities with enrollments under 15,000 students (Group I) should spend no less than $\$ 6,000$ annually for music materials to support an ongoing music curriculum. A new music program would of course require a larger initial expenditure. Multiplying the median number of music majors enrolled in Group I (274) by the median expenditure per music major $(\$ 28)$, a higher annual music materials budget for this group of $\$ 7,765$ is achieved. If one multiplies the mean number of music majors enrolled in Group I universities (263) by the mean expenditure per music major (\$41), a still higher annual music materials budget of $\$ 10$,728 is derived for the group.

The closely corresponding mean and median data from this study for libraries in universities with enrollments of 15,000 to 25,000 students (Group II) suggest a minimum annual music materials budget of $\$ 13,000$. However, multiplying the median number of music majors en- rolled in Group II (310) by the median expenditure per music major for this group ( $\$ 31$ ) yields a lower figure of $\$ 9,687$ for the minimum annual music materials budget for this group. Multiplying the mean number of music majors enrolled in Group II universities (327) by the mean expenditure per music major for this group ( $\$ 48$ ) yields a higher figure of $\$ 15,684$ for the minimum annual music materials budget. In this group the $\$ 13,000$ figure derived from the data is a middle figure rather than the lowest of the three possible as in Group I.

The mean and median figures on music materials budgets of libraries in universities with enrollments over 25,000 do not closely correspond as in the Group I and Group II models. The median budget $(\$ 14,250)$ is almost $\$ 3,000$ less than the mean $(\$ 17,123)$. Multiplying the median number of music majors enrolled in Group III (495) by the median library expenditure per music major (\$24) yields an even smaller figure of $\$ 12,088$. Applying the same procedure using mean data (510 music majors times $\$ 31$ per music major) yields $\$ 15,713$. It appears that a larger, more representative sample is needed in order to obtain a more stable model for Group III universities.

The Relationship of Subject Major Enrollment to Library Expenditures for Subject Materials

Accrediting agencies for the various academic subject areas take into consideration the holdings of the library and the funds to be spent by the library in continued support of that subject area. However, comparison of the 1969-70 library music material expenditures and university music major enrollments with the models derived from our study suggests that some music departments in universities are overenrolled in relation to the amount of supportive funds which 
TABLE 3

1969-70 University Library Expenditures PER Music Major

\begin{tabular}{|c|c|c|c|c|}
\hline School & $\begin{array}{l}\text { Average Budget for } \\
\text { Music Materials }\end{array}$ & $\begin{array}{l}\text { FTE Music } \\
\text { Majors }\end{array}$ & & $\begin{array}{l}\text { Library Expenditure } \\
\text { per Music Major }\end{array}$ \\
\hline \multicolumn{5}{|c|}{ Enrollments under 15,000} \\
\hline D & $\$ 5,000$ & $\begin{array}{l}\text { undergraduate } \\
\text { master's } \\
\text { doctoral }\end{array}$ & $\begin{array}{r}129 \\
122 \\
73\end{array}$ & \\
\hline C & 2,300 & $\begin{array}{l}\quad \text { Total } \\
\text { undergraduate } \\
\text { master's } \\
\text { doctoral }\end{array}$ & $\begin{array}{r}324 \\
25 \\
11 \\
7\end{array}$ & $\$ 15.43$ \\
\hline $\mathbf{E}$ & 7,000 & $\begin{array}{l}\quad \text { Total } \\
\text { undergraduate } \\
\text { master's } \\
\text { doctoral }\end{array}$ & $\begin{array}{r}43 \\
485 \\
20 \\
0\end{array}$ & $\$ 53.49$ \\
\hline F & 7,000 & $\begin{array}{l}\quad \text { Total } \\
\text { undergraduate } \\
\text { master's } \\
\text { doctoral }\end{array}$ & $\begin{array}{r}505 \\
199 \\
40 \\
8\end{array}$ & $\$ 13.86$ \\
\hline G & 3,581 & $\begin{array}{l}\quad \text { Total } \\
\text { undergraduate } \\
\text { master's } \\
\text { doctoral }\end{array}$ & $\begin{array}{r}247 \\
140 \\
35 \\
0\end{array}$ & $\$ 28.34$ \\
\hline I & 53,000 & $\begin{array}{l}\quad \text { Total } \\
\text { undergraduate } \\
\text { master's } \\
\text { doctoral }\end{array}$ & $\begin{array}{r}175 \\
400 \\
150 \\
50\end{array}$ & $\$ 20.46$ \\
\hline J & 9,175 & $\begin{array}{l}\quad \text { Total } \\
\text { undergraduate } \\
\text { master's } \\
\text { doctoral }\end{array}$ & $\begin{array}{r}600 \\
128 \\
27 \\
0\end{array}$ & $\$ 88.33$ \\
\hline L & 11,000 & $\begin{array}{l}\quad \text { Total } \\
\text { undergraduate } \\
\text { master's } \\
\text { doctoral }\end{array}$ & $\begin{array}{r}155 \\
48 \\
40 \\
36\end{array}$ & $\$ 65.65$ \\
\hline M & 3,500 & $\begin{array}{l}\quad \text { Total } \\
\text { undergraduate } \\
\text { master's } \\
\text { doctoral }\end{array}$ & $\begin{array}{r}124 \\
300 \\
10 \\
0\end{array}$ & $\$ 88.71$ \\
\hline \multicolumn{5}{|c|}{ Enrollments of 15,000 to 25,000} \\
\hline O & $\$ 6,292$ & $\begin{array}{l}\text { undergraduate } \\
\text { master's } \\
\text { doctoral }\end{array}$ & $\begin{array}{r}246 \\
64 \\
0\end{array}$ & \\
\hline$P$ & 13,000 & $\begin{array}{l}\quad \text { Total } \\
\text { undergraduate } \\
\text { master's } \\
\text { doctoral }\end{array}$ & $\begin{array}{l}\overline{310} \\
450 \\
300\end{array}$ & $\begin{array}{c}\$ 20.30 \\
\text { (master's + doctoral) }\end{array}$ \\
\hline & & Total & $\overline{750}$ & $\$ 17.33$ \\
\hline
\end{tabular}


TABLE 3 (Continued)

\begin{tabular}{|c|c|c|c|c|}
\hline School & $\begin{array}{l}\text { Average Budget for } \\
\text { Music Materials }\end{array}$ & $\begin{array}{l}\text { FTE Music } \\
\text { Majors }\end{array}$ & & $\begin{array}{l}\text { Library Expenditure } \\
\text { per Music Major }\end{array}$ \\
\hline R & 21,620 & $\begin{array}{l}\text { undergraduate } \\
\text { master's } \\
\text { doctoral }\end{array}$ & $\begin{array}{r}185 \\
37 \\
6\end{array}$ & \\
\hline $\mathrm{S}$ & 29,800 & $\begin{array}{l}\quad \text { Total } \\
\text { undergraduate } \\
\text { master's } \\
\text { doctoral }\end{array}$ & $\begin{array}{r}228 \\
48 \\
43\end{array}$ & $\begin{array}{c}\$ 94.82 \\
\text { (master's + doctoral) }\end{array}$ \\
\hline $\mathrm{T}$ & 4,250 & $\begin{array}{l}\quad \text { Total } \\
\text { undergraduate } \\
\text { master's } \\
\text { doctoral }\end{array}$ & $\begin{array}{r}91 \\
300 \\
30 \\
0\end{array}$ & $\$ 327.47$ \\
\hline $\mathrm{U}$ & 6,452 & $\begin{array}{l}\quad \text { Total } \\
\text { undergraduate } \\
\text { master's } \\
\text { doctoral }\end{array}$ & $\begin{array}{r}330 \\
249 \\
40 \\
21\end{array}$ & $\$ 12.88$ \\
\hline W & 5,600 & $\begin{array}{l}\quad \text { Total } \\
\text { undergraduate } \\
\text { master's } \\
\text { doctoral }\end{array}$ & $\begin{array}{r}310 \\
291 \\
54 \\
0\end{array}$ & $\$ 20.81$ \\
\hline $\mathrm{X}$ & 25,000 & $\begin{array}{l}\quad \text { Total } \\
\text { undergraduate } \\
\text { master's } \\
\text { doctoral }\end{array}$ & $\begin{array}{r}345 \\
90 \\
60 \\
20\end{array}$ & $\$ 13.33$ \\
\hline $\mathrm{Y}$ & 21,500 & $\begin{array}{l}\quad \text { Total } \\
\text { undergraduate } \\
\text { master's } \\
\text { doctoral }\end{array}$ & $\begin{array}{l}170 \\
950\end{array}$ & $\begin{array}{c}\$ 147.06 \\
\text { (Includes master's + } \\
\text { doctoral students) }\end{array}$ \\
\hline $\mathrm{Z}$ & 20,300 & $\begin{array}{l}\quad \text { Total } \\
\text { undergraduate } \\
\text { master's } \\
\text { doctoral }\end{array}$ & $\begin{array}{r}950 \\
195 \\
20 \\
0\end{array}$ & $\$ 22.63$ \\
\hline AA & 23,400 & $\begin{array}{l}\quad \text { Total } \\
\text { undergraduate } \\
\text { master's } \\
\text { doctoral }\end{array}$ & $\begin{array}{l}215 \\
345 \\
202\end{array}$ & $\begin{array}{c}\$ 94.42 \\
\text { (master's + doctoral) }\end{array}$ \\
\hline BB & 2,500 & $\begin{array}{l}\quad \text { Total } \\
\text { undergraduate } \\
\text { master's } \\
\text { doctoral }\end{array}$ & $\begin{array}{r}\overline{547} \\
30 \\
25 \\
25\end{array}$ & $\$ 42.78$ \\
\hline CC & 15,000 & $\begin{array}{l}\quad \text { Total } \\
\text { undergraduate } \\
\text { master's } \\
\text { doctoral }\end{array}$ & $\begin{array}{r}80 \\
200 \\
25 \\
12\end{array}$ & $\$ 31.25$ \\
\hline \multirow[t]{2}{*}{ EE } & 5,500 & $\begin{array}{l}\quad \text { Total } \\
\text { undergraduate } \\
\text { master's } \\
\text { doctoral }\end{array}$ & $\begin{array}{r}237 \\
287 \\
75 \\
12\end{array}$ & $\$ 63.29$ \\
\hline & & Total & 374 & $\$ 14.71$ \\
\hline
\end{tabular}


118 / College d Research Libraries • March 1971

TABLE 3 (Continued)

\begin{tabular}{|c|c|c|c|c|}
\hline School & $\begin{array}{l}\text { Average Budget for } \\
\text { Music Materials }\end{array}$ & $\begin{array}{l}\text { FTE Music } \\
\text { Majors }\end{array}$ & & $\begin{array}{l}\text { Library Expenditure } \\
\text { per Music Major }\end{array}$ \\
\hline FF & 14,000 & $\begin{array}{l}\text { undergraduate } \\
\text { master's } \\
\text { doctoral }\end{array}$ & $\begin{array}{r}332 \\
12 \\
0\end{array}$ & \\
\hline & & Total & 344 & $\$ 40.70$ \\
\hline \multicolumn{5}{|c|}{ Enrollments over 25,000} \\
\hline \multirow[t]{2}{*}{ GG } & $\$ 37,000$ & $\begin{array}{l}\text { undergraduate } \\
\text { master's } \\
\text { doctoral }\end{array}$ & $\begin{array}{r}241 \\
49 \\
0\end{array}$ & \\
\hline & & Total & 290 & $\$ 127.59$ \\
\hline \multirow[t]{2}{*}{$\mathrm{HH}$} & 26,000 & $\begin{array}{l}\text { undergraduate } \\
\text { master's } \\
\text { doctoral }\end{array}$ & $\begin{array}{r}345 \\
83 \\
39\end{array}$ & \\
\hline & & Total & 467 & $\$ 55.67$ \\
\hline \multirow[t]{2}{*}{ II } & 11,000 & $\begin{array}{l}\text { undergraduate } \\
\text { master's } \\
\text { doctoral }\end{array}$ & $\begin{array}{r}318 \\
67 \\
43 \\
\end{array}$ & \\
\hline & & Total & $\overline{428}$ & $\$ 25.70$ \\
\hline \multirow[t]{2}{*}{ JJ } & 32,000 & $\begin{array}{l}\text { undergraduate } \\
\text { master's } \\
\text { doctoral }\end{array}$ & $\begin{array}{l}400 \\
250\end{array}$ & (master's + doctoral) \\
\hline & & Total & 650 & $\$ 49.23$ \\
\hline \multirow[t]{2}{*}{ KK } & 24,000 & $\begin{array}{l}\text { undergraduate } \\
\text { master's } \\
\text { doctoral }\end{array}$ & $\begin{array}{r}1,002 \\
230 \\
240\end{array}$ & \\
\hline & & Total & $\overline{1,472}$ & $\$ 16.30$ \\
\hline \multirow[t]{2}{*}{ MM } & 5,900 & $\begin{array}{l}\text { undergraduate } \\
\text { master's } \\
\text { doctoral }\end{array}$ & $\begin{array}{r}410 \\
61 \\
38\end{array}$ & \\
\hline & & Total & 509 & $\$ 11.59$ \\
\hline \multirow[t]{2}{*}{ LL } & 17,213 & $\begin{array}{l}\text { undergraduate } \\
\text { master's } \\
\text { doctoral }\end{array}$ & $\begin{array}{r}600 \\
110 \\
90\end{array}$ & \\
\hline & & Total & 800 & $\$ 21.52$ \\
\hline \multirow[t]{2}{*}{$\mathrm{OO}$} & 10,500 & $\begin{array}{l}\text { undergraduate } \\
\text { master's } \\
\text { doctoral }\end{array}$ & $\begin{array}{r}350 \\
80 \\
0\end{array}$ & \\
\hline & & Total & 430 & $\$ 24.42$ \\
\hline \multirow[t]{2}{*}{ QQ } & 9,600 & $\begin{array}{l}\text { undergraduate } \\
\text { master's } \\
\text { doctoral }\end{array}$ & $\begin{array}{r}320 \\
111 \\
64\end{array}$ & \\
\hline & & Total & $\overline{495}$ & $\$ 19.39$ \\
\hline
\end{tabular}


TABLE 3 (Continued)

\begin{tabular}{|c|c|c|c|c|}
\hline School & $\begin{array}{l}\text { Average Budget for } \\
\text { Music Materials }\end{array}$ & $\begin{array}{l}\text { FTE Music } \\
\text { Majors }\end{array}$ & & $\begin{array}{l}\text { Library Expenditure } \\
\text { per Music Major }\end{array}$ \\
\hline \multirow[t]{2}{*}{ SS } & 14,250 & $\begin{array}{l}\text { undergraduate } \\
\text { master's } \\
\text { doctoral }\end{array}$ & $\begin{array}{r}189 \\
70 \\
51\end{array}$ & \\
\hline & & Total & $\overline{310}$ & $\$ 45.97$ \\
\hline \multirow[t]{2}{*}{ TT } & 9,550 & $\begin{array}{l}\text { undergraduate } \\
\text { master's } \\
\text { doctoral }\end{array}$ & 500 & $\begin{array}{c}\text { (Includes master's + } \\
\text { doctoral students) }\end{array}$ \\
\hline & & Total & $\overline{500}$ & $\$ 19.10$ \\
\hline
\end{tabular}

Analysis: Enrollments under 15,000-Nine libraries responding to the appropriate questions. Omitting high and low expenditure per music major, mean library expenditure per music major equals $\$ 40.79$.

Enrollments of 15,000 to 25,000-Fifteen libraries responding to the appropriate questions. Omitting high and low expenditures per music major, mean library expenditure per music major equals $\$ 47.96$.

Enrollments over 25,000: Eleven libraries responding to the appropriate questions. Omitting high and low expenditure per music major, mean library expenditure per music major equals $\$ 30.81$. Overall Analysis -35 academic libraries out of 98 receiving questionnaires responded to the appropriate questions. Overall average library expenditure per music major equals $\$ 36.33$.

their library is receiving for music materials. Fifteen of the thirty-five academic libraries responding to the appropriate questions can be cited as examples. Four Group I libraries, six Group II libraries, and five Group III libraries fall into this category. Fourteen of the fifteen libraries are in universities whose music departments are accredited by the National Association of Schools of Music. (For specific examples, see Table 3: libraries D, E, G, M, P, T, U, W, X, EE, KK, LL, $\mathrm{MM}, \mathrm{QQ}$, and TT.) Evidently in these cases accreditation by an accrediting agency also does not provide enough proof of the adequacy of library funding to a given subject area.

\section{The Need for Library Statistical In- formation at the Subject Level}

The three model music materials budgets derived from this study represent a very small part of the necessary continuing statistical analysis of subject areas represented in total budget re- quests of academic libraries. In the intrauniversity battle for the academic dollar, neither the reputation of the individual subject specialist nor accreditation by accrediting agencies are any longer evidence enough of the need for or adequacy of library materials in a given subject area. The comparative derivation of models is only one way in which to furnish another sort of supportive evidence to library administrators. Another useful parameter of any given subject area's profile would be a continuing statistical view of use as a factor influencing the need for duplicate copies within a subject area. There are many other sources of statistical evidence which could help to illuminate a budgetary profile for subject areas in university libraries. More statistical knowledge on the part of subject specialists of their subject collection and increased cooperation between these specialists for the development of a large data base are badly needed. 
TABLE 4

1969-70 Rankings of Universities Responding

\begin{tabular}{|c|c|c|c|c|c|c|c|c|}
\hline Rank & University & $\begin{array}{l}\text { 1969-70 FTE } \\
\text { Music Majors }\end{array}$ & Rank & University & $\begin{array}{c}\text { 1969-70 } \\
\text { Music } \\
\text { Materials } \\
\text { Budget }\end{array}$ & Rank & University & $\begin{array}{c}\text { 1969-70 } \\
\text { Library } \\
\text { Expenditure } \\
\text { per } \\
\text { Music Major } \\
\end{array}$ \\
\hline $\begin{array}{r}1 \\
2 \\
3 \\
4 \\
5 \\
6 \\
7 \\
8 \\
9 \\
10 \\
11 \\
12 \\
13 \\
14 \\
15 \\
16 \\
17 \\
18 \\
19 \\
20 \\
21 \\
22 \\
23 \\
24 \\
25 \\
26 \\
27 \\
28 \\
29 \\
30 \\
31 \\
32 \\
33 \\
34 \\
35\end{array}$ & $\begin{array}{l}\text { KK } \\
Y \\
\text { LL } \\
\text { P } \\
\text { JJ } \\
\text { I } \\
\text { AA } \\
\text { MM } \\
\text { E } \\
\text { TT } \\
\text { QQ } \\
\text { HH } \\
\text { OO } \\
\text { II } \\
\text { EE } \\
\text { W } \\
\text { FF } \\
\text { T } \\
\text { D } \\
\text { O } \\
\text { U } \\
\text { SS } \\
\text { M } \\
\text { GG } \\
\text { F } \\
\text { CC } \\
\text { R } \\
\text { Z } \\
\text { G } \\
\text { X } \\
\text { J } \\
\text { L } \\
\text { B } \\
\text { BB } \\
\text { C }\end{array}$ & $\begin{array}{r}1,472 \\
950 \\
800 \\
750 \\
650 \\
600 \\
547 \\
509 \\
505 \\
500 \\
495 \\
467 \\
430 \\
428 \\
374 \\
345 \\
344 \\
330 \\
324 \\
310 \\
310 \\
310 \\
310 \\
290 \\
247 \\
237 \\
228 \\
215 \\
175 \\
170 \\
155 \\
124 \\
91 \\
80 \\
43\end{array}$ & $\begin{array}{r}1 \\
2 \\
3 \\
4 \\
5 \\
6 \\
7 \\
8 \\
9 \\
10 \\
11 \\
12 \\
13 \\
14 \\
15 \\
16 \\
17 \\
18 \\
19 \\
20 \\
21 \\
22 \\
23 \\
24 \\
25 \\
26 \\
27 \\
28 \\
29 \\
30 \\
31 \\
32 \\
33 \\
34 \\
35 \\
36 \\
37 \\
38\end{array}$ & $\begin{array}{l}\text { I } \\
\text { JJ } \\
\text { S } \\
\text { HH } \\
\text { X } \\
\text { KK } \\
\text { AA } \\
\text { R } \\
\text { Y } \\
\text { Z } \\
\text { LL } \\
\text { CC } \\
\text { SS } \\
\text { FF } \\
\text { P } \\
\text { V } \\
\text { L } \\
\text { II } \\
\text { OO } \\
\text { QQ } \\
\text { TT } \\
\text { J } \\
\text { F } \\
\text { E } \\
\text { DD } \\
\text { U } \\
\text { O } \\
\text { MM } \\
\text { W } \\
\text { EE } \\
\text { D } \\
\text { T } \\
\text { G } \\
\text { M } \\
\text { BB } \\
\text { A } \\
\text { C }\end{array}$ & $\begin{array}{r}\$ 53,000 \\
37,000 \\
32,000 \\
29,800 \\
26,000 \\
25,000 \\
24,000 \\
23,400 \\
21,620 \\
21,500 \\
20,300 \\
17,213 \\
15,000 \\
14,250 \\
14,000 \\
13,000 \\
12,000 \\
11,000 \\
11,000 \\
10,500 \\
9,600 \\
9,550 \\
9,175 \\
7,000 \\
7,000 \\
6,500 \\
6,452 \\
6,292 \\
5,900 \\
5,600 \\
5,500 \\
5,000 \\
4,250 \\
3,581 \\
3,500 \\
2,500 \\
2,500 \\
2,300\end{array}$ & $\begin{array}{r}1 \\
2 \\
3 \\
4 \\
5 \\
6 \\
7 \\
8 \\
9 \\
10 \\
11 \\
12 \\
13 \\
14 \\
15 \\
16 \\
17 \\
18 \\
19 \\
20 \\
21 \\
22 \\
23 \\
24 \\
25 \\
26 \\
27 \\
28 \\
29 \\
30 \\
31 \\
32 \\
33 \\
34 \\
35\end{array}$ & $\begin{array}{l}\text { S } \\
\text { G } \\
\text { GG } \\
\text { R } \\
\text { Z } \\
\text { L } \\
\text { I } \\
\text { J } \\
\text { CC } \\
\text { HH } \\
\text { C } \\
\text { J } \\
\text { SS } \\
\text { AA } \\
\text { FF } \\
\text { BB } \\
\text { F } \\
\text { II } \\
\text { OO } \\
\text { Y } \\
\text { LL } \\
\text { U } \\
\text { G } \\
\text { O } \\
\text { QQ } \\
\text { TT } \\
\text { P } \\
\text { KK } \\
\text { D } \\
\text { EE } \\
\text { E } \\
\text { W } \\
\text { T } \\
\text { MM } \\
\text { M }\end{array}$ & $\begin{array}{r}\$ 327.47 \\
147.06 \\
127.59 \\
94.82 \\
94.42 \\
88.71 \\
88.33 \\
65.65 \\
63.29 \\
55.67 \\
53.49 \\
49.23 \\
45.97 \\
42.78 \\
40.70 \\
31.25 \\
28.34 \\
25.70 \\
24.42 \\
22.63 \\
21.52 \\
20.81 \\
20.46 \\
20.30 \\
19.39 \\
19.10 \\
17.33 \\
16.30 \\
15.43 \\
14.71 \\
13.86 \\
13.33 \\
12.88 \\
11.59 \\
11.29\end{array}$ \\
\hline
\end{tabular}

REFERENCES

1. Using the American Library Directory 1968/69, Directory of Special Libraries and Information Centers (1968 ed.), Directory of Music Research Libraries, A Preliminary Directory of Sound Re- cording Collections in the U.S. and Canada (ARSC), American Universities and Colleges (10th ed.), and Opening Fall Enrollment in Higher Education: Part B-Institutional Data 1968 (U.S. Office of Education) as sources for addresses, university enrollment statistics, and library music and phonorecord holdings. 